IJLR: International Journal of Law Recontruction

Volume 5, Number 1, April 2021

DOI : http://dx.doi.org/10.26532/ijlr.v5i1.15627

\title{
THE EFFECTIVENESS OF MAHKOTA WITNESSES (KROON GETUIDE) EVIDENCE ON NARCOTICS ABUSE
}

\author{
Yasmirah Mandasari Saragih \\ Panca Budi University \\ yasmirahmandasari@gmail.com \\ Muhammad Ridwan Lubis \\ Universitas of Moeslim Nusantara Al-Washliyah \\ muhammadridwanlubis76@gmail.com
}

\begin{abstract}
The use of Mahkota witnesses in Indonesia is still a matter of debate today, both among practitioners and academics, because there is no legal certainty regarding the use of this Mahkota witness. The research method uses juridical normative, the results obtained state that the effectiveness of the presence of Mahkota witnesses is to complete the minimum requirements for evidence to prove someone guilty. Where in the case of narcotics abuse, the lack of evidence found can facilitate the judicial process, the Mahkota witness is used to complete the truth to be revealed or material truth. The Mahkota witness does not affect the severity or lightness of the crime, but its usefulness is as a matter of convincing about the defendant's guilt or whether or not a narcotics abuse is proven. The testimony of the Mahkota witness has the power of proof if it is declared valid as a witness, there is no objection from the defendant's legal adviser regarding the presence of the Mahkota witness and the statement is stated before the court which has been sworn in beforehand and the information given is in accordance with the testimony given by other witnesses or tools other evidence so as to prove the defendant's guilt.
\end{abstract}

Keywords: Effectiveness, Mahkota Witness, Narcotics Abuse.

\section{A. INTRODUCTION}

Narcotics abuse has spread to some parts of the community in big cities and small cities, even traffickers are difficult to stop. The abuse of narcotics is used not for the purpose of treating illness, but is used deliberately to achieve a "certain consciousness" because of the effect of drugs on the soul. As Indonesian people, in general, currently are faced with a situation that is very difficult to worry about due to the rampant use, arbitrarily of various kinds of narcotics and psychotropic drugs. ${ }^{1}$ Basically the circulation of narcotics in Indonesia is very wide. Act No. 35 of 2009 concerning Narcotics has provided different treatment for narcotics abuse offenders. Narcotics users or addicts as narcotics offenders are imprisoned

1 Andri Winjaya Laksana, Tinjauan Hukum Pemidanaan Terhadap Pelaku Penyalahguna Narkotika Dengan Sistem Rehabilitasi, Jurnal Pembaharuan Hukum, Volume II No. 1 January-April 2015, page.74-85 
by the perpetrators of narcotics abuse. One of the efforts to save and normalize national life in accordance with the demands of reform is the need for a common vision, perception and mission of all state administrators and society. ${ }^{2}$

Solving problems regarding the crime of narcotics abuse becomes a very difficult job if it uses the usual evidence base. Proof is an activity of proving, where proving means showing existing evidence, doing something as truth, implementing, indicating, witnessing and convincing. Concretely, Adam Chazawi stated, that from the understanding of the meaning of evidence in court, actually proving activities can be divided into 2 (two) parts, namely:

1. Part of the disclosure of facts

2. Part of the work of analyzing facts which is also at the same time analyzing the law. ${ }^{3}$

There are five means of evidence according to Article 184 Paragraph

(1) of the Criminal Procedure Code, namely:

1. witness statement,

2. expert's statement,

3. letter,

4. instructions, and

5. statement of the defendant.

The evidence presented in court by the public prosecutor includes witness testimony, expert testimony, letters and statements of the defendant. Regarding the witness presented by the Public Prosecutor, 1 (one) of the witness statements is the testimony of the Mahkota witness who is also the Defendant in the same case but the prosecution was carried out separately (splitsing). This witness knew that he saw the incident himself because the witness was the defendant in the murder case. . Regarding the status of the Mahkota witness received by the Judge as evidence based on the judge's consideration in his decision, the Judge accepts the Mahkota witness testimony in this case as evidence for the witness testimony. ${ }^{4}$

The proof system, namely to support the objectives of the criminal procedural law is to seek and obtain or at least approach the material truth. ${ }^{5}$ But the ultimate goal of criminal procedural law is to achieve order, peace, peace, justice and prosperity in society. The application of the formulation of the proof system must be guided by the principles applicable in the criminal justice process, such as the presumption of innocence, and the principle of equality before the law. Based on the theory of evidence in

2 Yasmirah Mandasari Saragih, Problematika Gratifikasi Dalam Sistem Pembuktian Tindak Pidana Korupsi (Analisis Undang-Undang Nomor 31 Tahun 1999 Jo Undang-Undang Nomor 20 Tahun 2001 Tentang Pemberantasan Tindak Pidana Korupsi, Jurnal Hukum Responsif, Vol. 5 No. 5, October 2017, page.76-86

3 Adami Chazawi, Hukum Pembuktian Tindak Pidana Korupsi, Alumni, Bandung, 2006, page.21.

4 M Yahya Harahap, Pembahasan Permasalahan dan Penerapan KUHAP: Pemeriksaan Sidang Pengadilan, Banding, Kasasi, Peninjauan Kembali, Edisi Kedua, Sinar Grafika, Jakarta, 2007, page. 286-290.

5 Andi Hamzah, Hukum Acara Pidana Indonesia, Sinar Grafika, Jakarta, 2017, page.7 
criminal procedural law, almost all proof of criminal cases is always based on examination of witness testimony.

One way to prove a criminal case is to ask for help from other people called witnesses who are one of the evidence in the criminal procedure law. It is important for a witness to be at all stages of investigative and investigative activities, from the time the criminal act is known to the judicial process so that a Judge's Decision in Court is obtained. According to the law, what is called a witness is someone who can provide information for the purposes of investigation, prosecution and trial regarding a criminal case which he has heard himself, he has seen and experienced himself. Meanwhile, what is meant by witness testimony is one of the evidence in a criminal case in the form of testimony from a witness regarding a criminal event which he has heard himself, he has seen and experienced by himself by mentioning the reasons for his knowledge. ${ }^{6}$

The role of witnesses in every trial of a criminal case is very important because often witness testimony can influence and determine the likelihood of a judge's decision. A witness is considered to have the ability to determine the direction of the judge's decision. This gives an effect that every witness testimony has always received great attention, both by legal actors involved in the trial and by the legal observer community. ${ }^{7}$

A witness who is also a perpetrator in the same case in the practice of criminal justice is called a Mahkota witness. In the process of examination in court hearings, Mahkota witnesses who have the position as witnesses and defendants are often used in the same case. Mahkota witnesses are used because they can reveal legal facts and facts of events because Mahkota witnesses are people who know in detail about the planning, preparation, and implementation process so that a criminal act occurs. However, there are no specific laws and regulations regarding Mahkota witnesses but they are often used in the process of examination in court. Evidence is the central point of case examination in court. Evidence is provisions that contain outlines and guidelines on ways that are justified by law to prove the guilt charged to the accused and are also provisions that regulate evidence justified by law and which can be used by a judge to prove wrongdoing was indicted. ${ }^{8}$

The abuse of narcotics is a dangerous problem that can hamper the progress of the nation in carrying out development in all areas of life. ${ }^{9}$ Narcotics crime which is rife today is no longer carried out individually but involves many people and even has a wide network working neatly at the national and international levels. Narcotics have cost thousands of lives

6 Waluyadi, Kejahatan, Pengadilan dan Hukum Pidana, CV. Mandar Maju, Bandung, 2009, page. 134.

7 Muhadar, Edi Abdullah dan Husni Trhamrin, Perlindungan Saksi dan Korban Dalam Sistem Peradilan Pidana, CV. Putra Media Nusantara, Surabaya, 2009, page. 1

8 Bastianto Nugroho, Peranan Alat Bukti Dalam Perkara Pidana Dalam Putusan Hakim Menurut KUHAP, Jurnal Hukum Yuridika, Vol 32 No. 1, 2017, page. 23.

9 Carto Nuryanto, Reconstruction Of The Criminal Sanction Policy And Action (Double Track System) In Law Enforcement For Narcotic Crime Prevention Reffered To Religious Justice, Jurnal Pembaharuan Hukum, Volume V No.3 September-December 2018, page.339-354 
every day, in this case it is often experienced by teenagers who are sitting in school, and not a few teenagers have lost their future because of being caught in illegal drugs. The reason is that many people do not really understand the impact that can occur when using narcotics, besides that there is a need for counseling for the community and awareness among humans and it is hoped that they can stay away from drugs.

In various proving trials of Narcotics criminal cases, evidence known as Mahkota witnesses has emerged. The term Mahkota witness is not found in the laws and regulations governing criminal procedural law in Indonesia, but the definition of Mahkota witness is quoted from the Supreme Court Decision Number 2437 K/Pid.Sus/2011 which states that: "Although an authentic definition is not given in the Criminal Procedure Code. Regarding Mahkota witnesses (kroongetuide), however based on an empirical perspective, Mahkota witnesses are defined as witnesses who originate or are taken from one of the suspects or other defendants who have jointly committed a criminal act, and in which case the witness is given a Mahkota. The Mahkota given to the witness with the status of the Defendant is in the form of negating the prosecution of the case or the imposition of a very light charge if the case is transferred to the Court or is forgiven for wrongdoing. ${ }^{10}$

The use of evidence for Mahkota witness testimony can only be seen in criminal cases in the form of participation, and splitsing has been carried out against these criminal cases since the preliminary examination process at the investigation level. In addition, the appearance and use of Mahkota witnesses in criminal cases where the separation was carried out was based on the reasons for the lack of evidence to be submitted by the Public Prosecutor. From the understanding between practice and doctrine, it can be concluded that there are pros and cons regarding the witness testimony (Mahkota) in Indonesia relating to human rights, especially against witnesses and suspects or defendants, namely: Opinions that are pro to witness testimony (Mahkota). ) is a person considered a Mahkota witness in case of splitting, so he becomes a witness in case $A$, and becomes the defendant in case $\mathrm{B}^{11}$

The use of Mahkota witnesses in Indonesia is still a matter of debate today, both among practitioners and academics, because there is no legal certainty regarding the use of this Mahkota witness. Some parties argue that the use of Mahkota witnesses is permissible because it aims to achieve a sense of public justice. If in an event of a criminal act which is to reveal facts related to the perpetrator's actions or about the chronology of the criminal incident, it is very important to have witnesses who saw, heard and experienced this for themselves. However, if there are no witnesses who meet these requirements, it will be very difficult to reveal the facts of the incident. Therefore, the public prosecutor presents a Mahkota witness in the

10 Gorby Zefanya Tahitu, Keberadaan Saksi Mahkota Dalam Sistem Peradilan Pidana Indonesia, Lex Crimen, Vol. IV No. 1 Jan-Mar 2015, page.164-177

11 I Made Sukadana, Amiruddin \& Lalu Parman, Alat Bukti Keterangan Saksi Mahkota Dalam Perkara Pidana Pencurian, Jurnal Law Reform, Volume 14, Nomor 2, 2018, 262-274 
trial process because the Mahkota witness is one of the defendants who is a witness in a case who is considered to know and experience the crime. ${ }^{12}$

The purpose of this writing is to find out, understand, and analyze the effectiveness of evidence with the Mahkota witness in the crime of narcotics abuse so that we can understand whether or not the evidence is valid by using testimony from the Mahkota witness in the crime of narcotics abuse.

\section{B. RESEARCH METHODS}

This study uses a normative legal research method approach. Normative law is a method or method used by examining existing library materials. ${ }^{13}$ Legal research with a normative doctrinal approach, or normative juridical legal research or normative legal research is basically an activity that examines the internal aspects (to solve problems that exist in) the internal of positive law. "This is done as a consequence of the view that law is an autonomous institution that does not have any relationship with other social institutions. Therefore, law as a system has the ability to live, grow and develop within its own system. ${ }^{14}$

\section{RESULT AND DISCUSSION}

\section{The Effectiveness of Mahkota Witnesses Evidence on Narcotics Abuse}

The Law of Evidence Rules contain the intention and effort to state the truth of an event, so that reason can be accepted regarding the truth of the incident. Whereas in general, the provisions which outline and procedural guidelines that are justified by law prove the guilt of the accused, the trial must not arbitrarily prove the guilt of a defendant. Meanwhile, proof according to Martiman Projohamidjojo can be interpreted as a whole of the legal elements of proof that are related and related to one another and influence each other in a whole or unanimity. ${ }^{15}$

Evidence in ordinary criminal law is provided for in Article 183 of the Criminal Procedure Code which reads: "A judge may not impose a sentence on a person unless at least two valid pieces of evidence are convinced that a criminal act actually occurred and that the defendant was the one who was guilty of committing it." The formulation of the article shows that the system or theory of proof based on the law

12 Ni Made Elly Pradnya Suari, I Made Minggu Widyantara, Ni Made Sukaryati Karma, Kedudukan Dan Perlindungan Saksi Mahkota Dalam Tindak Pidana Pencurian Dengan Kekerasan (Studi Kasus Pengadilan Negeri Denpasar), Jurnal Interpretasi Hukum, Vol. 1, No. 1 August 2020 page. $210-215$

13 Soerjono Soekanto dan Sri Mamudji, Penelitian Hukum Normatif Suatu Tinjauan Singkat, PT Raja Grafindo Persada, Jakarta, 2009, page.13.

14 Kornelius Benuf, Muhamad Azhar, Metodologi Penelitian Hukum sebagai Instrumen Mengurai Permasalahan Hukum Kontemporer, Jurnal Gema Keadilan, Volume 7 Edisi I, June 2020, page.20-33

15 Setyo utomo, Pembalikan Beban Pembuktian Tindak Pidana Korupsi (Asas Praduka Tidak Bersalah Dalam Negara Hukum), Sofmedia, Jakarta, 2014, page.153. 
negatively (Negatief Wettelijk) animates the formulation of the article. ${ }^{16}$

From the description, it is clear that the Criminal Procedure Code adheres to a system of proof negatife wettlijk namely:

a. Wettelik : the existence of valid evidence as stipulated by law.

b. Negatife : There is a conviction (conscience) of the judge, that is, based on this evidence the judge believes the defendant's guilt.

In the criminal act of narcotics, the articles that are charged against the defendant are various, such as: Article 144 (intermediary), Article 112 (possession), Article 127 (user). Most of the narcotics abuse group I is carried out together or participating.

The crime of narcotics abuse group I collectively or it can also be referred to as a criminal act of inclusion. Inclusion or deelneming is regulated in Article 55 and Article 56 of the Criminal Code. According to Adami Chazawi, the definition of inclusion (deelneming) is a definition that includes all forms of participation or involvement of a person or persons both psychologically and physically by committing each act so as to give birth to a criminal act. ${ }^{17}$

Inclusion ordeelneming issues can be divided according to their nature in independent inclusion. Included in this type are those who commit and participate in committing criminal acts. The accountability of each participant is assessed or respected individually for all actions or actions taken. Forms of participation that do not stand alone. Included in this type are persuades, assistants and those who order to commit a criminal act. The accountability of one participant depends on the actions of the other participant.

Based on these articles, participation is divided into two major divisions, namely:

a. Maker/dader (Article 55 of the Criminal Code) which consists of:

1) pleger

2) doenpleger

3) madepleger

4) uitlokker

b. Helper/madeplichtige (Article 56 of the Criminal Code) which consists of:

1) Helper at the time the crime was committed

2) Helper before the crime is committed. ${ }^{18}$

Perpetrator is a person who commits an act which fulfills the formulation of the offense and is considered the most responsible for the crime. ${ }^{19}$ The provisions of Article 55 of the Criminal Code first state who committed or committed a criminal act in a complete manner. Even though a perpetrator (plagen) is not a participant (deelnemer), it is understandable why he needs to be mentioned. The perpetrator, in

16 Bastianto Nugroho, Op.Cit, page.17-36

17 Adam Chazawi, Op.Cit. page.21

18 Fahrurrozi, Samsul Bahri M Gare, Sistem Pemidanaan Dalam Penyertaan Tindak Pidana Menurut Kuhp, Media Keadilan Jurnal Ilmu Hukum, Volume 10 Nomor 1, April 2019, page.50-63

19 Teguh Prasetyo, Hukum Pidana, Rajawali Pers, Depok, 2017, page. 206. 
addition to other parties who have participated in or been involved in a criminal act that has been committed, will be convicted jointly with him as the perpetrator (dader), while the method of participation is carried out and the responsibility for him is also determined by the connection with the criminal act committed by the perpetrator. Therefore, the perpetrator (plegen) is a person who fulfills all the elements of the offense (also in the form of an experiment or preparation), including when it is done through other people or their subordinates. ${ }^{20}$

According to Adami Chazawi, the person who orders to do or make a messenger or Doenpleger is a person who does an act with someone else's intermediary, while the intermediary is only used as a tool. Thus, there are two parties, namely the direct maker (manus ministralauctor physicus), and indirect maker (manus dominal auctor intellectualis). ${ }^{21}$

The elements in doenpleger are: The tools used are humans, the tools used are doing, the tools used cannot be justified. Meanwhile, the things that cause the tool (material maker) to be accountable are; If he is not fully developed in spirit (Article 44), If he acts because of coercion (Article 48), If he acts because of an illegal position order (Article 51 Paragraph (2), If he is misguided (wrong) regarding one of the elements of offense, If he does not have the purpose required for the crime concerned, in which juridically the person who is ordered to and finally actually commits the criminal act must be a person who cannot be criminally responsible. According to the explanation of the Criminal Code, there are two elements in doing plegen. a person, namely a human being, who is used as a tool by the offender. This is the main and special element of doen plegen. Second, the person who is used as a tool is a connection or an extension of the arm of another person who ordered that person. ${ }^{22}$

The strength of proof of the Mahkota witness in the trial of narcotics abuse class I with participation is as valid evidence and has the power of proof because it has fulfilled the requirements, namely:

a. The witness testimony given must be on oath, this is regulated in Article 160 Paragraph (3) of the Criminal Procedure Code.

According to the provisions of Article 160 paragraph (3) of the Criminal Procedure Code, before a witness testifies: "is obliged to say" an oath or promise. As for the oath or promise:

1) Performed according to their respective religious ways.

2) Pronounce an oath or promise containing that the witness will give a truthful testimony that is nothing other than the truth. ${ }^{23}$

20 Jan Remmelink, Hukum Pidana, PT. Gramedia Pustaka Utama, Jakarta, 2003, page. 308

21 Adam Chazawi, Op.Cit. page. 24

22 Chant S. R. Ponglabba, Tinjauan Yuridis Penyertaan Dalam Tindak Pidana Menurut KUHP, Lex Crimen, Vol. VI/No. 6/Ags/2017, page.31-37

23 Ticka Pratiwi dan Novena Winda P, Keabsahan Pemberian Kesaksian Oleh Seseorang Yang Mempunyai Hubungan Keluarga Sedarah Dengan Terdakwa di Persidangan, Jurnal Verstek, Vol. 1 No. 1, 2016, page.194-202 
b. The witness testimony given in court is what the witness has seen, heard and experienced by the witness himself, this is regulated in Article 1 point 27 of the Criminal Procedure Code.

c. Testimonium de auditu or witness testimony which is a re-form of someone else's story, does not have the value of the information as evidence. Likewise, the opinion or conjecture that the witness gets from the results of thoughts cannot be considered as valuable information as evidence. ${ }^{24}$

1) Witness statements must be given in court, this is in accordance with Article 185 Paragraph (1) of the Criminal Procedure Code. Statements outside court proceedings have no value as evidence.

2) The testimony of a witness is considered insufficient. In order to have the power of proof, the testimony of a witness must be supplemented and provided with other evidence, this is in accordance with Article 185 Paragraph (2) of the Criminal Procedure Code.

3) The statements of witnesses who are presented in court proceedings have mutual relations or are related and mutually reinforce the truth of a certain situation or incident, this is in accordance with Article 185 Paragraph 4 of the Criminal Procedure Code. However, the testimony of the Mahkota witness still requires the judge's judgment and consideration to determine whether the Mahkota witness can be used as a valid witness evidence and has the power of proof, because the Mahkota witness does not have the perfect power of proof and binds the judge, the judge has the freedom to judge. The requirements for the Witness's Information so that it can be used as valid evidence must meet two requirements, namely:

4) The formal requirement is that the witness testimony can only be considered valid if it is given under oath. Witness testimony that is not under oath may only be used as a supplement to legal testimony.

5) The material requirement is that the testimony of a witness alone cannot be considered valid as a means of proof (Unus Testis Nulus Testis). ${ }^{25}$ However, the testimony of a witness is sufficient as a means of proving one of the elements of the alleged crime.

The presence of a Mahkota witness in a narcotics abuse trial has a considerable degree of effectiveness. This is because the presence of a Mahkota witness can be a complement to law enforcement officials in proving a case that is difficult to find evidence. Mahkota witness is a valid evidence used as a legal basis. The presence of the Mahkota witness

24 Ibid.

25 Darwan Prinst, Hukum Acara Pidana Dalam Praktik, Edisi Revisi, Djambatan, Jakarta, 2019, page. 139 
turned into a fresh wind when the law enforcement officials had no more evidence other than a letter from the urine examination. As previously explained, the use and role of Mahkota witnesses is valid evidence.

According to R. Soesilo, the Mahkota witness is the witness presented from several defendants or one of the defendants in order to prove the guilt of the accused; Mahkota witnesses can be exempted from criminal charges or later prosecuted separately depending on the discretion of the public prosecutor concerned. ${ }^{26}$ Lilik Mulyadi has his own definition of a Mahkota witness, namely a witness who comes from or is taken from one of the suspects or another accused who has jointly committed a criminal act, and in which case the witness is given a Mahkota: as for the Mahkota that is given to a witness who has the status the defendant is in the form of negated the prosecution of his case or is forgiven for wrongdoing. ${ }^{27}$

The existence of Mahkota witnesses in the process of proving criminal cases in Indonesia is very vulnerable, especially the lack of legal protection for Mahkota witnesses. There are several factors that lead to weak legal protection for Mahkota witnesses, including the absence of due process of law in the examination of Mahkota witnesses. This is due to the absence of laws and regulations on criminal procedure law that regulate Mahkota witnesses and their specific protection that can be used as a reference. Even if there are still scattered here and there in various special criminal laws and regulations as well as other laws that are general in nature and do not specifically regulate the protection of Mahkota witnesses.

The Mahkota witness is a powerful means of proof to reveal and expose organized crime, both in the form of scandal crimes and serious crimes in criminal acts. ${ }^{28}$ The Mahkota witness can be used as a proving tool in exposing new dimensions of crimes, such as acts of corruption. The crime prototype that shifts from conventional methods demands a balance in the world of legal proof where the method of disclosure is no longer possible to rely on conventional methods.

Normatively, the submission and use of Mahkota witnesses is against the principles of a fair trial and is also a violation of human rights principles as regulated in the Criminal Procedure Code as a national legal instrument and the International Covenant on Civil and Political Rights (ICCPR) 1996 as an international human rights instrument. ${ }^{29}$

Because of this situation, the practice of examining Mahkota witnesses in court is still ongoing, which is only based on practice in judicial practice. The role of witness is equated with an ordinary witness,

26 R.Soesilo, Teknik Berita Acara (Proses Verbal), Ilmu Bukti, dan Laporan, Politeia, Bogor, 1980, page 7.

27 Lilik Mulyadi, Putusan Hakim Dalam Hukum Acara Pidana : Teori, Praktik, Teknik Penyusunan dan Permasalahannya, Citra Aditya Bakti, Bandung, 2007, page. 80.

28 Firman Wijaya, Whistle Blower dan Justice Collaborator, Dalam perspektif Hukum, Printed by Penaku, Jakarta, 2006, page.17

29 Sitti Nurhayati Syamsuningsih, Perlindungan Hukum Terhadap Saksi Mahkota Dalam Perkara Tindak Pidana Korupsi, e Jurnal Katalogis, Volume 4 Nomor 7, July 2016, page.1-12 
therefore before the Mahkota witness gives his testimony, the witness is sworn in according to the provisions of the Criminal Procedure Code with the aim of his testimony being used as valid evidence. However, because the position of the Mahkota witness at that time was also a defendant, the judge usually gave a notification that if the testimony he gave before the trial was a lie or false testimony, the witness could be subject to additional sanctions, namely for false testimony which is punishable by Article 242 of the Criminal Code.

\section{Criminal Liabilities of Mahkota Witness Evidence on Drug Abuse}

Specific and limitative arrangements regarding the rights and obligations of Mahkota witnesses will be the main way to resolve problems of their position and role in proving criminal cases. So far, the examination of the Mahkota witness has caused polemics, both at the academic level and in empirical practice, which still creates a dichotomy of pros and cons. To eliminate this dichotomy, it is very relevant to regulate the rights and obligations of Mahkota witnesses.

According to Rusdiharjo, as quoted by Muhadar et al., The Mahkota witness in practice in Indonesia was first used in the case of labor rights activist Marsinah. A contradiction in this is shown by the idea of the chief justice who rejected the use of Mahkota witnesses. This term is prohibited by the Supreme Court from being used. Mahkota witnesses occur due to the lack or absence of witnesses in the cases being held. Usually the witnesses are the suspects or defendants. In practice, this was carried out in cases with dellneming nuances or inclusion, where the perpetrator consisted of several people, so that there was a connection between one defendant and another. ${ }^{30}$

In contrast to the practice in Indonesia, according to Andi Hamzah in the Netherlands and Italy, a Mahkota witness (kroon geutuige) is applied, namely the suspect/defendant because he wants to expose his friends' organized crime, in return he is removed from the list of defendants and made a witness, for example when he wants to expose crimes of corruption, narcotics and terrorism. ${ }^{31}$

Perpetuating Witnesses, Reporters and experts, including people who can provide information relating to a criminal case even though they have not heard it themselves, they have not seen it themselves, and they have not experienced it themselves, as long as that person's statement is related to a criminal act With due observance of the rights of witnesses and victims mentioned above, it can be seen that specifically and limitatively the rights of the perpetrator witness (Mahkota witness) are clear.

Such clarity certainly has a positive impact on the process of proving criminal cases, because investigators, public prosecutors, judges, and other related parties have legal certainty regarding what can be

30 Muhandar, Edi Abdullah, Husni Thamrin, Op.Cit, page.5.

31 Indriyanto Seno Adji, Humanisme dan Pembaharuan Penegakan Hukum, Kompas, Jakarta, 2009, page.157 
protected against Mahkota witnesses. Moreover, judges in the examination of the Mahkota witnesses will pay close attention to the extent to which the protection of the rights of the Mahkota witnesses in proving criminal cases in court is carried out in accordance with the laws and regulations of the applicable criminal procedure law.

In addition to the rights of Mahkota witnesses described above, it is necessary to balance the obligations of Mahkota witnesses to uphold a fair and impartial trial. This means that the Mahkota witness also needs to be burdened with legal obligations in connection with the rights that have been given to him. The obligations of the Mahkota witness are as follows:

a) The Mahkota witness is obliged to provide truthful information, none other than the truth, so as not to mislead the ongoing judicial process;

b) A Mahkota witness is obliged to have a good faith to remove the dark veil of crime and the perpetrators to become bright, so that the general public feels safe because he is protected from the criminals;

c) The Mahkota witness is obliged not to collaborate in giving false information to save his friends and protect the major crimes that lie behind him;

d) The Mahkota witness is obliged to follow instructions or orders from the LPSK or other institutions in the framework of protecting himself, his family and his assets in accordance with the provisions of the prevailing laws and regulations;

e) The Mahkota witness is obliged to follow all judicial processes in the framework of him being the perpetrator's witness, and even if he is declared a suspect because of the information he has voluntarily provided, he is obliged to surrender himself to undergo the legal process, in order to comprehensively clarify the settlement of the problem.

f) If the Mahkota witness does not fulfill his obligations properly, then the protection given to him by law must be revoked, and if he is later proven guilty, he must be punished as fairly as possible. ${ }^{32}$

The Criminal Procedure Code does not prohibit the use of Mahkota witnesses. This arrangement regarding Mahkota witnesses was originally regulated in Article 168 of the Criminal Procedure Code. Article 168 of the Criminal Procedure Code basically does not prohibit a person who is jointly suspected of committing a criminal act from becoming a witness in a criminal case. In contrast to the status of a Defendant whose testimony can only be used against himself (Article 189 KUHAP), the use of a suspect's testimony is not explicitly regulated in the Criminal Procedure Code. However, over time, the situation in which a witness is also a suspect or defendant in a criminal case, in practice is possible and is

32 Ismail, Peranan Saksi Mahkota Dalam Proses Pembuktian Perkara Pidana di Indonesia, tesis, Program Studi Magister Ilmu Hukum Fakultas Hukum Universitas, Hasanuddin Makassar, 2018, page.145-146 
often known as a Mahkota witness. ${ }^{33}$

The power of witness Mahkota as a means of evidence in proving the crime of narcotics has the power of free evidence where it does not have the power of perfect proof, does not determine and is not binding so that judges are required to be careful, thorough, and thorough. The testimony of the Mahkota witness has the power of proof if it is declared valid as a witness, there is no objection from the defendant's legal adviser regarding the presence of the Mahkota witness and the statement is stated before the court which has been sworn in beforehand and the information given is in accordance with the testimony given by other witnesses or tools other evidence so as to prove the defendant's guilt. $^{34}$

\section{CONCLUSION}

Based on this writing which aims to find out, understand, and analyze the effectiveness of evidence with the Mahkota witness in the crime of narcotics abuse the presence of Mahkota witnesses is to complete the minimum requirements for evidence to prove someone guilty. Where in the case of narcotics abuse, the lack of evidence found can facilitate the judicial process, the Mahkota witness is used to complete the truth to be revealed or the material truth. The Mahkota witness does not affect the severity or lightness of the crime, but its usefulness is as a matter of convincing about the defendant's guilt or whether or not a narcotics abuse is proven. The testimony of the Mahkota witness has the power of proof if it is declared valid as a witness, there is no objection from the defendant's legal adviser regarding the presence of the Mahkota witness and the statement is stated before the court which has been sworn in beforehand and the information given is in accordance with the testimony given by other witnesses or tools other evidence so as to prove the defendant's guilt.

\section{BIBLIOGRAPHY}

\section{Books:}

Adami Chazawi, 2016, Hukum Pembuktian Tindak Pidana Korupsi, Alumni, Bandung;

Andi Hamzah, 2017, Hukum Acara Pidana Indonesia, Sinar Grafika, Jakarta;

Darwan Prinst, 2019, Hukum Acara Pidana Dalam Praktik, Edisi Revisi, Djambatan, Jakarta;

33 Sulfiati, Kamri Ahmad, Abdul Agis, The Role Of The Mahkota Witnesses In Proofing The Criminal Action Of Narcotics In The Makassar State Court, Meraja Journal, Vol 3, No. 3, November 2020, page.351-363.

34 Nadia Febriani, Haryadi, Dessy Rakhmawati, Penggunaan Saksi Mahkota (Kroongetuige) dalam Pembuktian di Persidangan Terhadap Tindak Pidana Narkotika, PAMPAS: Journal Of Criminal, Volume 1 Nomor 2, 2020, page.43-67 
Firman Wijaya, 2006, Whistle Blower dan Justice Collaborator, Dalam perspektif Hukum, Printed by Penaku, Jakarta;

Indriyanto Seno Adji, 2009, Humanisme dan Pembaharuan Penegakan Hukum, Kompas, Jakarta;

Ismail, 2018, Peranan Saksi Mahkota Dalam Proses Pembuktian Perkara Pidana di Indonesia, tesis, Program Studi Magister Ilmu Hukum Fakultas Hukum Universitas, Hasanuddin Makassar;

Jan Remmelink, 2003, Hukum Pidana, PT. Gramedia Pustaka Utama, Jakarta;

Lilik Mulyadi, 2007, Putusan Hakim Dalam Hukum Acara Pidana : Teori, Praktik, Teknik Penyusunan dan Permasalahannya, Citra Aditya Bakti, Bandung;

M Yahya Harahap, 2007, Pembahasan Permasalahan dan Penerapan KUHAP: Pemeriksaan Sidang Pengadilan, Banding, Kasasi, Peninjauan Kembali, Edisi Kedua, Sinar Grafika, Jakarta;

Muhadar, Edi Abdullah dan Husni Trhamrin, 2009, Perlindungan Saksi dan Korban Dalam Sistem Peradilan Pidana, CV. Putra Media Nusantara, Surabaya;

R.Soesilo, 1980, Teknik Berita Acara (Proses Verbal), IImu Bukti, dan Laporan, Politeia, Bogor;

Setyo utomo, 2014, pembalikan beban pembuktian tindak pidana korupsi (asas praduga tidak bersalah dalam negara hukum), Sofmedia, Jakarta;

Soerjono Soekanto dan Sri Mamudji, 2009, Penelitian Hukum Normatif Suatu Tinjauan Singkat, PT Raja Grafindo Persada, Jakarta;

Teguh Prasetyo, 2017, Hukum Pidana, Rajawali Pers, Depok;

Waluyadi, 2009, Kejahatan, Pengadilan dan Hukum Pidana, CV. Mandar Maju, Bandung;

\section{Journals:}

Andri Winjaya Laksana, Tinjauan Hukum Pemidanaan Terhadap Pelaku Penyalahguna Narkotika Dengan Sistem Rehabilitasi, Jurnal Pembaharuan Hukum, Volume II No. 1 January-April 2015;

Bastianto Nugroho, Peranan Alat Bukti Dalam Perkara Pidana Dalam Putusan Hakim Menurut KUHAP, Jurnal Hukum Yuridika, Vol 32 No. 1, 2017;

Carto Nuryanto, Reconstruction Of The Criminal Sanction Policy And Action (Double Track System) In Law Enforcement For Narcotic Crime Prevention Reffered To Religious Justice, Jurnal Pembaharuan Hukum, Volume V No.3 September-December 2018;

Chant S. R. Ponglabba, Tinjauan Yuridis Penyertaan Dalam Tindak Pidana Menurut KUHP, Lex Crimen, Vol. VI No. 6 Ags 2017; 
Fahrurrozi, Samsul Bahri M Gare, Sistem Pemidanaan Dalam Penyertaan Tindak Pidana Menurut Kuhp, Media Keadilan Jurnal Ilmu Hukum, Volume 10 Nomor 1, April 2019;

Gorby Zefanya Tahitu, Keberadaan Saksi Mahkota Dalam Sistem Peradilan Pidana Indonesia, Lex Crimen, Vol. IV No. 1 Jan-Mar 2015;

Kornelius Benuf, Muhamad Azhar, Metodologi Penelitian Hukum sebagai Instrumen Mengurai Permasalahan Hukum Kontemporer, Jurnal Gema Keadilan, Volume 7 Edisi I, June 2020;

I Made Sukadana, Amiruddin \& Lalu Parman, Alat Bukti Keterangan Saksi Mahkota Dalam Perkara Pidana Pencurian, Jurnal Law Reform, Volume 14, Nomor 2, 2018;

Nadia Febriani, Haryadi, Dessy Rakhmawati, Penggunaan Saksi Mahkota (Kroongetuige) dalam Pembuktian di Persidangan Terhadap Tindak Pidana Narkotika, PAMPAS: Journal Of Criminal, Volume 1 Nomor 2, 2020;

Ni Made Elly Pradnya Suari, I Made Minggu Widyantara, Ni Made Sukaryati Karma, Kedudukan Dan Perlindungan Saksi Mahkota Dalam Tindak Pidana Pencurian Dengan Kekerasan (Studi Kasus Pengadilan Negeri Denpasar), Jurnal Interpretasi Hukum, Vol. 1, No. 1 August 2020;

Sitti Nurhayati Syamsuningsih, Perlindungan Hukum Terhadap Saksi Mahkota Dalam Perkara Tindak Pidana Korupsi, e Jurnal Katalogis, Volume 4 Nomor 7, July 2016;

Sulfiati, Kamri Ahmad, Abdul Agis, The Role Of The Mahkota Witnesses In Proofing The Criminal Action Of Narcotics In The Makassar State Court, Meraja Journal, Vol 3, No. 3, November 2020;

Ticka Pratiwi dan Novena Winda P, Keabsahan Pemberian Kesaksian Oleh Seseorang Yang Mempunyai Hubungan Keluarga Sedarah Dengan Terdakwa di Persidangan, Jurnal Verstek, Vol. 1 No. 1, 2016;

Yasmirah Mandasari Saragih, Problematika Gratifikasi Dalam Sistem Pembuktian Tindak Pidana Korupsi (Analisis Undang-Undang Nomor 31 Tahun 1999 Jo Undang-Undang Nomor 20 Tahun 2001 Tentang Pemberantasan Tindak Pidana Korupsi, Jurnal Hukum Responsif, Vol. 5 No. 5, October 2017. 